\title{
Proverbs and Idioms in Children's Books*
}

\author{
Zeynel Hayran \\ Correspondence: Zeynel Hayran, Department of Teaching Turkish, Faculty of Education, Ahi Evran University, Kırsehir, \\ Turkey.
}

Received: September 19, 2017

Accepted: October 17, 2017

Online Published: October 30, 2017

doi:10.11114/jets.v5i12.2661

URL: https://doi.org/10.11114/jets.v5i12.2661

\begin{abstract}
In this study, it was searched for the extent to which proverbs and idioms were included in the children's books that were taught to elementary school students. Children's books which are taught at the stage of children's vocabulary enriched rapidly and significantly, present the vocabulary of the mother tongue and its universe of meaning to a child. The richness of a vocabulary provides superiority to the students in terms of human relations and their learning. Proverbs which are one of the elements that constitute the vocabulary of Turkish; are concise words that reflect society's wisdom, experiences, and expression power; idioms, on the other hand, are a stereotyped phrase which states a concept or a situation with an attractive narrative and which also has a side meaning. The method of this study is to document review. Within the scope of the study, children's books that are taught to elementary school students are described in terms of their use of proverbs and idiomatic expressions. The results obtained from the research are discussed in the light of literature, and suggestions for the researchers, teachers and authors are presented with the collected findings.
\end{abstract}

Keywords: native language/mother tongue, comprehension, expression, interaction, vocabulary

\section{Introduction}

In this study, the answer was searched to what extend proverbs and idioms were mentioned in children's books. Teachers, who are engineers in creating terminal behavioral change (Senemoglu, 2011), teachers teach to read children's books to the students to support their development both at school and at outside the school. Of order to help and extend the range of their thinking, the teacher (Cullingford, 1998:199) needs to make a conscious effort to introduce new words. According to Sever (2013a:145), children's books are the first original language models printed in children's language as a means of introducing the vocabulary of children's mother-tongue to children, expressing the structure of it, its characteristics, the expression power of the language. Children's books who enrichs children's emotions and thoughts with linguistic and visual communication, support children's linguistic development, understanding and narration skills (Yalcin \& Aytas, 2016:76) in the direction of objectives.

The phase in which children's vocabulary enriched considerably and rapidly (Kavcar, Oguzkan \& Hasirci, 2016:15) is the elementary school period. Children's books that are read and are listened heard during this period introduce the vocabulary of the child's mother tongue and the universe of meaning. The books that are prepared according to children's language development and meaning stages of the children present a language environment (Sever, 2013b:36) for children that are reflected in all the richness of the Turkish vocabulary. The richness of the vocabulary existence gives students superiority in terms of human relations and learning; however there is insufficient research into the extent to which children's books represent the vocabulary in terms of proverbs, idioms, dilemna, and etc. Until now, the sufficiency of children's books in terms of vocabulary hasn't been determined. According to Bas (2006:125), a number of determinations should be made through investigations, the situation of the children's books should be shown in terms of the vocabulary, with the different, planned and intricate works to be done, the vocabulary of children's literature books should be determined.

\subsection{Proverbs}

The vocabulary consists words, proverbs, idioms, stereotypes, terms and various patterns of expression. At the same time, the vocabulary also reflects the material and spiritual cultures of the spoken nation, worldview, living conditions, and

${ }^{*}$ This study was supported within the framework of Ahi Evran University Scientific Research Projects, no: EGT. E2.16.023 
many years of experience (Akbarian, 2012:1-19; Aksan, 2000:7-13; Aksoy, 1998a:27). More elaborately stated, proverbs are short, generally known sentences of the folk that contain wisdom, truths, morals, and traditional views in a metaphorical, fixed, and memorizable form and that are handed down from generation to generation (Mieder, 2004:2). By reviving and concretizing them, the proverbs that show examples (Hatiboglu, 1981:191) by analogy with the transmissions they want to give to the embodied beings are anonymous, concise words that reflect the wisdom, experiences (Turkyilmaz, 2015; Basgoz, 2006:87), and power of expression of the society. The proclamation how social events and phenomenons occur (Aksan, 2000: 180-189; Aksoy,1998a: 17-19; Bascom, 1954: 333-349), the necessity of taking lessons from social events; teaching ethics and giving advice guiding; customs and traditions, beliefs are the general characteristics of proverbs. In according Stone (2006), proverbs are common to nearly all cultures, both ancient and modern, literate and non-literate. Generally speaking, proverbs are popular sayings that express commonly held truths, with their chief ingredients, being sense, shortness. Shortness is certainly one of them, with the average length of a proverb consisting of about seven words (Meider, 2004:7). According to Aksan (1993, 2005), Basgoz (1993:127-142) and Elcin (1981:685), proverbs are very successful because of their rhetorics such as very original, analogy (similitude), metephor, quasi, contradiction (contrast) etc. and since they are impressive, easily remembered, poetic narrative. It expresses the thought in an indirect way from the analogy (Eyuboglu, 1973:XX). Sometimes, it is difficult to understand what some instances of proverbs really mean (Akbarian, 2012:1-19). In proverbs, amphiboly, lethargy, promiscuity (Boratav, 2003:148) and expression and style plays are avoided. Our proverbs tell us the best way to make judgments and give advice: "many a little makes a mickle", "if you lie down with dogs you will rise up with fleas", "hills remain apart forever, (but) people do meet (someday)" (Hatiboglu, 1972:81).

\subsection{Idioms}

Idioms are a linguistic aspect of a language-speaking society that reflects worldview, lifestyle, environmental conditions, traditions, customs and beliefs, important assets and concepts, in short, material and spiritual cultures, (Aksan, 1993: 83), which are also important in terms of literature and folklore. Idioms are word templates which drift out of reasonin order to increase the power of expression and in which some words haven't changed, some have changed. The common feature of all world expressions is that the words go out of their true meaning, they create new concepts away from their original meanings (Elcin, 1981:706) or even out of logic. Idioms are established with at least two, at most seven, eight words (Hatiboglu, 1981:194-195). The phrase is a stereotyped word-phrase or sentence (Aksoy, 1998b:52), which expresses a concept, a situation, either in an attractive narrative or in a special structure, and in many cases has a separate meaning from its true meaning. The common features of idioms are; The phrases are stereotyped phrases or excerpts that express concepts in metaphor (alteration), in expressiveness and authenticity; the majority being two judges and rhyming; side features based on a tale or phenomenon; that some of the side features of customs, beliefs, traditions are reported; the stereotyping of some; it is a declining narrative form; some of them are made up of dilemmas, these are the common features of idioms (Aksan, 2000:171-180; Aksoy, 1998a:40-52).

\subsection{Related Studies}

Yurt (2016) brought words, roots and trunks in the stories to determine the vocabulary of Aytul Akal's tale book "Balloons in sky"; the word frequency index of the work was created. As a result, the work is rich in terms of vocabulary and idioms, and other elements of speech (proverbs, pattern words) are insufficient.

Bas (2012) is in the list of Primary School's One Hundred Basic Readings and explores the loyalty of fairy tales that are most likely to encounter, read, and listen to students. A common pool was created with all the vowel elements in the selected tables as examples, and the word, special name, doublet, idiom and proverbs contained therein were determined separately. While quantitative data on the vocabulary are shown, frequently used vocabulary elements are also listed in the study. The links of the most commonly used lyric items to the tale type, the role of the verb on the word list in the formation of storytelling (storytelling/narration) was evaluated. It is also addressed to children's contribution to the development of the vocabulary in the light of the sentence clause.

Bagci (2010) tried to determine the perception levels of the proverbs and idioms of primary school students. "The Proverbs and Idioms Perceptions Test" developed by the researcher was applied because of the opinion that primary school students should be able to use and perceive the proverbs and idioms in all the activities they will perform the four basic language skills as a sign of their native language proficiency. Based on the results obtained from the research, proposals have been made for the use of proverbs and idioms in the development of reading, listening, speaking and writing language skills of elementary school first graders.

According to Bas (2006:125), to what extent children's literature products represent vocabulary in terms of elements like basic vocabulary, idioms, proverbs, duplication hasn't been clarified in our country yet. Until now, the sufficiency of children's books in terms of vocabulary hasn't been determined. 
In this study, it has been sought to answer to what extent the proverbs and idioms are included in children's books written by master authors according to their child's characteristics (Oguzkan, 2000) and which are taught to elementary school students and affect their "language development", "cognitive development", "personality development" and "social development". The findings are supported digitally and graphically. The results obtained from the research are discussed in the light of the information in the field, and suggestions for the researchers and teachers are presented within the collected findings.

\section{Method}

This method of study is a document review. Document examination can be defined as the collection and examination of written visual material (Sonmez \& Alacapinar, 2014:95-96; Yildirim \& Simsek, 2011:118). It can be used in both quantitative and qualitative research. According to Karasar (2011:183), a document review covers finding, reading, grading and evaluating resources for a specific purpose. In the document review, it is essential to analyze the written materials containing information about the cases or phenomena targeted to be investigated. In the scope of the study, children's books read to elementary school students are described in terms of their use of proverbs and idioms. By using Okuyan (2009), Maltepe (2011) and Sever (2013) studies, the criteria of the appropriate book for primary school students were determined. In accordance with the opinions of the teachers and experts, twenty books were selected from each author, including Turkish and translations. In the research, the works of Aksoy (1998)'s Proverbs and Idioms Dictionary I, II and Yurtbasi (2013a; 2013b)'s Classified dictionary of proverbs and Classified dictionary of idioms were utilized in verifying the proverbs.

\section{Findings}

In order to compare the examined children's books with each other in terms of the usage of proverbs and idioms, the proverb and the idiom frequencies of each work are calculated (Saglam, 2004:48).

$$
\text { Proverb / idiom frequency }=\frac{\text { Total Number of Proverb / idiom }}{\text { Number of children's book pages }}
$$

Table 1. Frequency and percentage values of proverbs in children's books

\begin{tabular}{|c|c|c|c|c|}
\hline \multirow{2}{*}{ 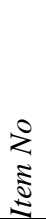 } & \multirow{2}{*}{ Children's Books } & \multirow{2}{*}{ 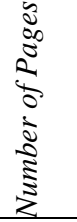 } & \multicolumn{2}{|c|}{ Proverbs } \\
\hline & & & $f$ & $\%$ \\
\hline 1 & Ozdemir, E. (2005). The master of a happy country (Mutlu kentin yoneticisi). Ankara:Kok. & 135 & 10 & 0.074 \\
\hline 2 & $\begin{array}{l}\text { Behramoglu, A. (2014). The tale of manly youngster and flying horse (Yigitler yigiti ve } \\
\text { ucan at masali). Istanbul:Can. }\end{array}$ & 88 & 4 & 0.045 \\
\hline 3 & Kaya, Z. (2010). Wildflower (Kir cicegi). Ankara:Phoenix. & 117 & 3 & 0.026 \\
\hline 4 & Sayman, A. (2015). As Evliya Celebi (Evliya Celebi gibi). Istanbul:Kirmizi Kedi. & 121 & 3 & 0.025 \\
\hline 5 & Koseoglu, H. (2012). Flower of highland (Yayla cicegi) Izmir:Tudem. & 152 & 2 & 0.013 \\
\hline 6 & Oner, C. (2016).Gulibik. Istanbul:Can. & 78 & 1 & 0.013 \\
\hline 7 & Ak, S. (2002). Puf, pufpuf, cuf, cufcuf and cino. Istanbul:Can. & 81 & 1 & 0.012 \\
\hline 8 & Sertbarut, M. (2005). Hidden things by the fog (Sisin sakladiklari). Izmir:Tudem. & 205 & 2 & 0.010 \\
\hline 9 & Gokturk, A. (130).King's fleas (Kralın piresi). Istanbul:Yapi Kredi. & 130 & 1 & 0.008 \\
\hline 10 & Dolek, S. (2015). Green slope. (Yesil bayir). Ankara:Bilgi. & 144 & 1 & 0.007 \\
\hline 11 & Dayioglu, G. (2010). Fadis. Istanbul:Altin Kitaplar. & 160 & 1 & 0.006 \\
\hline 12 & Adali, B. (2012). House with hyacinth (Sumbullu kosk). Istanbul:Can. & 74 & 0 & 0 \\
\hline 13 & $\begin{array}{l}\text { Aksoy, S. K. (2015). Sugar girl and magical apple (Seker kiz ve buyulu elma). } \\
\text { Istanbul:Can. }\end{array}$ & 78 & 0 & 0 \\
\hline 14 & Behrengi, S. (2016). Little black fish (Kucuk kara balik) Istanbul:Can. & 62 & 0 & 0 \\
\hline 15 & Ak, B. (2009). Child who loves boats (Vapurları seven çocuk). Istanbul: Gunisigi. & 94 & 0 & 0 \\
\hline 16 & $\begin{array}{l}\text { Cakman, K. A. (2016). White crow and the master with bushy moustache (Karga beyaz ve } \\
\text { posbiyik usta). Istanbul:Can. }\end{array}$ & 82 & 0 & 0 \\
\hline 17 & Cinaroglu, A. (1998). The city with seven doors (Yedi kapili kent). Istanbul:Uçanbalik & 32 & 0 & 0 \\
\hline 18 & Dahl, R. (2007). Bad fox (Yaman tilki). Istanbul:Can. & 104 & 0 & 0 \\
\hline 19 & Härtling, P. (2015). Grandfather is moving (Buyukbaba taşiniyor). Istanbul:Gunisigi. & 141 & 0 & 0 \\
\hline 20 & $\begin{array}{l}\text { Nöstlinger, C. (2017). Konrad or the child from the tin box (Konrad ya da konserve } \\
\text { kutusundan cikan cocuk). Istanbul:Can. }\end{array}$ & 174 & 0 & 0 \\
\hline
\end{tabular}


According to Table 1, "The master of a happy country" (Mutlu kentin yoneticisi) is the most prolific children's literature work with $\mathrm{f}=10, \% .074$. The proverbs used are "Such is the way it goes" (p.57), "Trouble shared is a trouble halved" (p.92), "Friend in need is friend indeed" (p.53), "Two heads are better than one" (p.65), "There's no point crying over spilt milk" (p. 80), "Last regret doesn't mean anything" (p.80), "Who separated from the herd is covered by wolf" (p.81), "Soft answer turneth away wrath" (p.41) "Who stays alone will captured by the wolves" (p.81) and "Animals smell, people talk" (p.40). No proverb can be found from nine books out of twenty children's books. The use of the appropriate proverbs in children's books (Temizyurek, Sahbaz \& Guler, 2016: 243) is important both in moral development and in the perception of the subtleties of the mother tongue. In terms of frequency values, the first 10 proverbs in all children's books in Table 1; "Trouble shared is a trouble halved" (2), "Once you trespass, you twist slowly in the wind" (2), "Friend in need is friend indeed" (2), "One doesn't need a guide when the village is in sight" (2), "Cometh the hour cometh the man" (2), "Such is how it goes" (1), "Two heads are better than one" (1), "He who lives by the sword, shall die by the sword" (1), "Who separated from the herd is covered by wolf" (1), and "Soft answer turneth away wrath" (1). The proverbs and subject matter in the book were very child-centered.

Table 2. Frequency and percentage values of expressions in children's books

\begin{tabular}{|c|c|c|c|c|}
\hline \multirow[b]{2}{*}{$\begin{array}{l}z_{z} \\
\equiv \\
\Xi\end{array}$} & \multirow{2}{*}{ Children's Books } & \multirow{2}{*}{ 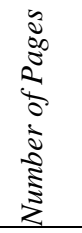 } & \multicolumn{2}{|c|}{ Idioms } \\
\hline & & & $f$ & $\%$ \\
\hline 1 & Behrengi, S. (2016). Little black fish (Kucuk kara balik) Istanbul:Can. & 62 & 107 & 1.73 \\
\hline 2 & Cinaroglu, A. (1998). The city with seven doors (Yedi kapili kent). Istanbul:Uçanbalik & 32 & 53 & 1.66 \\
\hline 3 & Dayioglu, G. (2010). Fadis. Istanbul:Altın Kitaplar. & 160 & 200 & 1.25 \\
\hline 4 & Dolek, S. (2015). Green slope. (Yesil bayir). Ankara:Bilgi. & 144 & 167 & 1.16 \\
\hline 5 & Ak, S. (2002). Puf, pufpuf, cuf, cufcuf and cino. Istanbul:Can. & 81 & 88 & 1.09 \\
\hline 6 & Ozdemir, E. (2005). The master of a happy country (Mutlu kentin yoneticisi). Ankara:Kok. & 135 & 10 & 0.074 \\
\hline 7 & Härtling, P. (2015). Grandfather is moving (Buyukbaba taşiniyor). Istanbul:Gunisigi. & 141 & 145 & 1.03 \\
\hline 8 & Sayman, A. (2015). As Evliya Celebi (Evliya Celebi gibi). Istanbul:Kirmizi Kedi. & 121 & 100 & 0.83 \\
\hline 9 & Sertbarut, M. (2005). Hidden things by the fog (Sisin sakladiklari). Izmir:Tudem. & 205 & 157 & 0.77 \\
\hline 10 & Gokturk, A. (130). King's fleas (Kralin piresi). Istanbul:Yapi Kredi. & 130 & 99 & 0.76 \\
\hline 11 & Dahl, R. (2007). Bad fox (Yaman tilki). Istanbul:Can. & 104 & 79 & 0.76 \\
\hline 12 & Adali, B. (2012). House with hyacinth (Sumbullu kosk). Istanbul:Can. & 74 & 48 & 0.65 \\
\hline 13 & Kaya, Z. (2010). Wildflower (Kir cicegi). Ankara:Phoenix. & 117 & 69 & 0.59 \\
\hline 14 & $\begin{array}{l}\text { Aksoy, S. K. (2015). Sugar girl and magical apple (Şeker kiz ve buyulu elma). } \\
\text { Istanbul:Can. }\end{array}$ & 78 & 45 & 0.58 \\
\hline 15 & Oner, C. (2016). Gulibik. Istanbul:Can. & 78 & 41 & 0.53 \\
\hline 16 & $\begin{array}{l}\text { Nöstlinger, C. (2017). Konrad or the child from the tin box (Konrad ya da konserve } \\
\text { kutusundan cikan cocuk). Istanbul:Can. }\end{array}$ & 174 & 88 & 0.51 \\
\hline 17 & $\begin{array}{l}\text { Behramoglu, A. (2014). The tale of manly youngster and flying horse (Yigitler yigiti ve } \\
\text { ucan at masali). Istanbul:Can. }\end{array}$ & 88 & 40 & 0.45 \\
\hline 18 & Koseoglu, H. (2012).Flower of highland (Yayla cicegi) Izmir:Tudem. & 152 & 64 & 0.42 \\
\hline 19 & Ak, B. (2009). The child who loves boats (Vapurlarl seven çocuk). Istanbul:Gunisigi. & 94 & 17 & 0.18 \\
\hline 20 & $\begin{array}{l}\text { Cakman, K.A. (2016). White crow and the master with bushy moustache (Karga beyaz ve } \\
\text { posbiyik usta). Istanbul:Can. }\end{array}$ & 82 & 9 & 0.11 \\
\hline
\end{tabular}

According to Table 2, "Little black fish (Kucuk kara balik)" is a work of children's literature which used the phrase with $\mathrm{f}=107,1.725 \%$ among the examined books. The 10 idioms used multiple times are, "wend one's way" (p.13, 31, 35 and 38), "go off one's rocker" (p.14, 41, 47), "mislead" ( p. 15, 24, 38), "set at odds" (p.40, 46), "not sleep a wink" (p.12, 52), "get above oneself" (s.21, 23), "get above oneself" (p.9, 49), "agree to give in marriage" (p.12, 41), "put a bee in someone's bonnet (about something)" (p.41, 47) and "go wrong" (p.13, 34). In all twenty children studied have identified idioms. According to the findings, the richness of translation children's books in terms of idioms can be attributed to their translators being competent on both levels. The first 10 idioms in all children's books in Table 2 in 
terms of frequency values are, "start off" (15), "put a bee in someone's bonnet (about something)" (13), "drop out of sight" (10), "prick up one's ears" (9), "catch someone's attention" (8), "become speechless" (7), "have one's heart in one's mouth" (6), "shrug one's shoulders" (5), be too sorry to say a word" (4) and "can't believe what one hear" (3).

\section{Conclusion and Discussion}

It is mentioned that in the field of speech learning of the 4th grade of primary education, "In speaking, they must be given the use of idiom, proverb, rhyme, corn, concise words and metaphors, and humorous things"; and in the field of writing and learning, the activity of "Find Proverbs" can be done, strengthen writing, use idioms, proverbs, adjectives, and so on. are encouraged (MEB, 2009:79-89) to use. According to the findings, the percentage of proverbs in children's books is insufficient. Previous researches are also supporting these results. Bas (2006) examines 100 texts and found 9 proverbs, Gundogdu (2012) examines a book and found one proverb and Sen (2009) examines various texts and found 14 proverbs in them. If a person is alien to the semantic plane of the proverb and doesn't know in what context it is used, he will perceive the "shown" in the proverb, however, the concern not understanding what the "intended" is, it may be one of the reasons why authors don't include proverbs in children's books. However, cognitive structures, which are common ways of knowing for everyone, constantly change and reorganize as a result of maturation and gaining experience. In children's books translated from other tongues into Turkish, the lack of prominence in the proverbs may be attributed to translation from one language to another. There are two main reasons for the difficulty in translating proverbs and idioms from one language to another (Saglam, 2001): The first is the difference between languages, or rather, between the source language and target language constructs. The second is the judgment of previous generations, transmitted through proverbs and idioms on the foreign side. observation and living conditions are the cultural affiliations of the translator. The fact that a significant number of authors don't include proverbs in their works can be explained by the relatively low frequency of the proverb (Saglam, 2004:60), the new development model emerging from rural to urban migration, rapid urbanization and industrialization. The vocabulary in modern children's fiction and in traditional juvenile fiction reflect cultural changes in terms of vanished or highly restricted words (Knowles \& Malmkjær, 1996:266), and changes in patterns of collocation. According to Hatiboglu (1972:188), some proverbs carry traces of nomadic-rural life. In this respect, the meanings and words in proverbs are so obsolete that the proverb has fallen from its use. Children's books are important in terms of introducing the rich expression possibilities of the language, such as words, idioms, terms, phrases, proverbs, etc. that constitute the vocabulary of the child's mother tongue. The main responsibility falls on writers of children's books primarily when the vocabulary of language and the power of expression are involved in the works of children's literature (Okuyan, 2009). Visual materials should be used in the teaching of idioms and proverbs in the lessons, since proverbs and idioms can't be processed with any visual material such as pictures, cartoons, etc. (Bagci, 2010), because they can reduce the ability to perceive and understand idioms and proverbs; because visuals make it easier for children to perceive abstract concepts (Sever, 2013a:189). Otherwise, there will be new generations who aren't dominant in the mother tongue, lacking in verbal and written narration, and lacking enough knowledge of the Turkish vocabulary (Aksan, 2001:157).

\subsection{Recommendations}

The following are suggestions for researchers, teachers and authors in the light of data and literature obtained as a result of the research:

1. By taking advantage of linguistic data, the writers can place more emphasis on linguistic loyalty in children's books, taking into account frequency schedules.

2. A study can be made on proverbs and idioms in youth books read to secondary school students.

3. The teachers can read books that reflect Turkish vocabulary.

\section{References}

Akbarian, I. (2012). What counts as a proverb? The case of NTC's dictionary of proverbs and clichés. Lexikos, 22, 1-19. https://doi.org/10.5788/22-1-994

Aksan, D. (1993). The power of Turkish. Ankara:Bilgi.

Aksan, D. (2000). The vocabulary of Turkish. Ankara:Engin.

Aksan, D. (2001). The past, present, tomorrow of Turkish. Ankara:Bilgi.

Aksoy, O. A. (1998a). Proverbs and idioms dictionary I. Istanbul:Inkilap.

Aksoy, O. A. (1998b). Proverbs and idioms dictionary II. Istanbul:Inkilap.

Bagci, H. (2010). The level of perception of the proverbs and idioms of the 5th grade students of primary education. TUBAR, XXVII, Spring, 91-110.

Bas, B. (2006). A research on the vocabulary of fortune texts written in the field of children's literature between 
1985-2005 (Unpublished doctoral dissertation). Gazi University Educational Sciences Institute, Turkish Education Department, Turkey.

Bas, B. (2012). An assessment of the vocabulary of Turkish traditions. Milli Folklor, 93, 125-134.

Bascom, W. R. (1954). Four functions of folklore. The Journal of American Folklore, 67(266), 333-349. https://doi.org/10.2307/536411

Basgoz, I. (1993). Proverb image, proverb message, and social change. Journal of Folklore Research, 30(2/3), 127-142.

Basgoz, I. (2006). Proverbs or the social meaning of proverbs. (Trans.: N. T.Tocoglu). Milli Folklor, 18(70), 85-91.

Boratav, P. N. (2003). Turkish folk literature in 100 questions. Istanbul:K Kitapligi.

Cullingford, C. (1998). Children's literature and its effects-the formative years. London:Cassell.

Elcin, S. (1981). Introduction to folk literature. Ankara: Akcag.

Eyuboglu, E. K. (1973). Proverbs and idioms in poetry and folk language. Istanbul:Dogan Kardes.

Gundogdu, A. E. (2012). An application based on the vocabulary-review based on Turkish children's literatüre (Unpublished master's thesis). Institute of Educational Sciences of the University of Mersin, Turkey.

Hatiboglu, V. (1972). The Turkic syntax. Ankara:Turk Dil Kurumu.

Hatiboglu, V. (1981). Dilemma in Turkish language. Turkish Language Institution. Ankara:Turk Dil Kurumu.

Karasar, N. (2011). Scientific research method. Ankara:Nobel.

Kavcar, C., Oguzkan, A. F., \& Hasirci, S. (2016). Turkish teaching. Ankara:Ani.

Knowles, M., \& Malmkjær, K. (1996). Language and control in children's literature. London:Routladge.

Maltepe, S. (2011). Pre-service Turkish language teachers' opinions on acquiring competencies in special field. e-Journal of New World Sciences Academy, 6(2), 1868-1877.

MEB. (2009). Turkish primary education curriculum (1-5). Ankara:MEB.

Meider, W. (2004). Proverbs:A handbook. London: Greenwood.

Oguzkan, F. (2000).Children's literature. Ankara:Ani.

Okuyan, H. Y. (2009). Criteria for choosing children's literature products used in reading hours of Turkish and classroom teachers. Mehmet Akif Ersoy University Faculty of Education Journal, 18, 135-159.

Sağlam, M. Y. (2001).Imagination in proverbs and idioms. Hacettepe University Journal of Literature, 18(1), 45-51.

Saglam, M. Y. (2004). Proverbs: Our lost cultural heritage. Ankara:Urun.

Sen, E. (2009). A examination of the literary texts of the writers of indigenous children's theater, which scobe daily child literature from 1980. (Unpublished master's thesis). Institute of Social Sciences of the University of Yuzuncu Yil, Turkey.

Senemoglu, N. (2011). Development, learning and teaching. Ankara:PEGEM.

Sever, S. (2013a). Children and literature. Izmir:TUDEM.

Sever, S. (2013b). Children's literature and reading culture. Izmir:TUDEM.

Sonmez, V., \& Alacapinar, F. G. (2011). Selected scientific research methods. Ankara:Ani.

Stone, J. R. (2006).The routledge book of world proverbs. New York:Routledge.

Temizyurek, F., Sahbaz, N. K., \& Guler, Z. (2016). Children's literature. Ankara:PEGEM.

Turkyilmaz, M. (2015). Investigation of Turkish proverbs in terms of children's rights. Zeitschrift für die Welt der Turken, 7(1), 221-236.

Yalcin, A., \& Aytas, G. (2016). Children's literature. Ankara:Akcag.

Yildirim, A., \& Simsek, H. (2011). Qualitative research methods in the social sciences. Ankara:Seckin.

Yurt, S. U. (2016). Aytul Akal's speech about the tale book called "balloons in the sky". Erzincan University Education Faculty Journal, 18(1), 425-444.

Yurtbasi, M. (2013a). A dictionary of classified Turkish proverbs. Istanbul:Excelling.

Yurtbasi, M. (2013b). A dictionary of classified idioms. Istanbul:Excelling.

\section{Copyrights}

Copyright for this article is retained by the author(s), with first publication rights granted to the journal.

This is an open-access article distributed under the terms and conditions of the Creative Commons Attribution license which permits unrestricted use, distribution, and reproduction in any medium, provided the original work is properly cited. 